\title{
TAX BALANCE IN AGRIBUSINESS AS A TYPE OF SPECIAL BALANCE
}

\author{
Ivan Milojević ${ }^{1}$, Milorad Zekić2 ${ }^{2}$, Zvonko Gobeljic ${ }^{3}$
}

\begin{abstract}
Resume
The tendency of continuous compounding of business processes inevitably leads to application of increasingly complex instruments for the purposes of financial reporting in agribusiness. In this system the existential place and role of individual elements that alter the existing and acquire new functions comes into question.

Balancing implies a regulated and consistent system in which every change leads to the creation of new relations and changing already established relationships. In this regard, in this paper we will focus on the place and role of tax balance in the group of special balances in agribusiness, as a very significant group of accounting instruments. Displaying information for users and situations in which they are used, balances gain their place in this classification.

For the purposes of applying financial instruments, referring primarily to balances in agribusiness, it is necessary to know the way of their classification according to their functions. From this aspect, tax balance in agribusiness is a specific report, both in terms of its formal and material structure, which gives it the basis to belong to ordinary as well as special types of balances in agribusiness.
\end{abstract}

Key words: taxes, balancing, financial reports, agribusiness, company.

JEL: M41, H25, Q13.

1 Ivan Milojević Ph.D., Full Professor, University of Business Studies Banja Luka, Jovana Dučića 23a, Republika Srpska, BiH, Phone: +381 600702697 E-mail: drimilojevic@gmail.com

2 Milorad Zekić Ph.D., University of Business Studies Banja Luka, Jovana Dučića 23a, Republika Srpska, BiH, Phone: Phone: +387 65365 365; E-mail: m.zekic22@gmail.com

3 Zvonko Gobeljić Ph.D., Assosiate Professor, John Naisbitt university, Faculty of Culture and Media, Goce Delčeva 8, Belgrade, Republic of Serbia, Phone: +381112203011, E-mail: zvonko.gobeljic@gmail.com

EP 2015 (62) 3 (767-780) 


\section{Introduction}

Balance occupies a special place in financial reporting in agribusiness when it comes to instruments that include business events. Tax balance in agribusiness as a specific type of balance in financial reporting represents the feedback between a business (trade) and tax law, which is the basis for functioning of all agribusiness subjects on the territory which is under jurisdiction of this kind of legislation.

It crucial to mention that knowing tax balancing in agribusiness, its structure and basic characteristics is the basis for successful management of agribusiness subjects. Tax balance in agribusiness belongs to a wide family of balances, and as such it can and must be classified by relevant criteria in groups as related wholes. The classification criteria can be numerous, but for us the most important ones are those based on which balances are differentiated, depending on when they are drafted whether they are being based on tax or business law norms. Tax balance in agribusiness by its formal and material base belongs to a group of balances that are based on tax regulations and as such is undisputed in this group.

By reviewing this criterion of differentiation the question of whether tax balance sheet is in fact a special balance cannot be omitted. A number of authors who have discussed this problem have tried to find an answer this question. According to some, tax balance should be classified in the group of special balances, while for others tax balance can be classified into regular balances.

We will look for the answer to this question in the criterion that is used during classification of tax balance in the group of special balances. This would mean that if tax balance was looked at from the standpoint of regularity of preparation in a company, we would classify it as a regular balance. On the other hand, we have the fact that it actually respects tax regulation norms and must therefore be in the group of special balances. In our case, tax balance due to its material characteristics is classified into a broader group of special balances, balances on the character of the income sheet of an agribusiness.

Features that characterize tax balance sheet in agribusiness will most easily be identified by comparing this balance sheet with related balances, which will, by comparative method give a complete picture of this type of balance. Respecting tax legal norms, the role of tax balance in agribusiness as a special type of balance arises.

Because tax balance in agribusiness belongs to the group of balances, as such it has the characteristics and principles that apply to other balances.

\section{Balance in agribusiness as an accounting instrument}

Name tax balance refers to a word of Latin origin "bilancia" which indicates a balancing scale with two weighing pans. In economic theory, different definitions of balance are used, in order to represent and in the clearest way bring closer to the public the meaning of balance, so among a wide range of definitions some can be extracted: 
1. The word balance is used to show formally leveled parts of assets and capital (Rankovic, 2013);

2. Balance shows the situation at a given point in time (Žager, Žager, 1999).

The most comprehensive definition of balance that is used is that the balance is a twosided tabular summary overview of state of assets and their sources or expenditures and revenues (Milojevic, 2010).

All of this which was brought out goes for the tax balance in agribusiness as well, but to that extent in which tax balance in agribusiness is actually sustainable.

From the name, next to the guideline which it is about, we can see that it contains the word tax which gives it another guideline that determines the purpose of its existence as well. The word tax points to the function that it performs or the goal that was set before it in agribusiness.

The goal that was set before tax balance in agribusiness is for it to clearly display and determine the taxable basis of the taxpayer in agribusiness. Within tax balances in agribusiness, revenues and expenses are clearly defined and shown in order to determine taxes. Tax balance contains information that is important not only for determining income tax, but also other types of taxes in agribusiness that will in perspective constitute one common format that will be conjoined.

From the goal of tax balance in agribusiness its functions are derived, which at first glance aren't recognizable. Functions of tax balance in agribusiness are different and we can classify them depending on the users of this report.

1. Country as the user of tax balance in agribusiness, in the foreground points out the function of determining taxable income and total tax, which represents budget revenue for the country. Governments and their agencies are interested in resource allocation and therefore for the activities of a company (Milojević, Pejić, 2010). The reasons of why they are interested in tax reports are numerous: help in lending, assistance in export promotion, privatization and the like which at first glance are not a priority.

2. Management of an agribusiness company can most accurately gain insight into the company's operations and the amount of income tax from tax statements, which for the company represents one of the more serious expenses. These users point out the comparison feature of the balance, in order to be able to manage it, on the position of their company compared to other companies in agribusiness (Savić, et. al. 2014) because the precision of expressing positions makes that possible and leaves the choice when planning revenue and expenditure for a tax period to managing bodies.

3. Owners view tax balance in agribusiness as a report that gives them a true picture on the state of revenue and expenditure, which puts the allocative function in the foreground, which from the point of view of the owner is very important when nvesting capital. 
4. The creditors are interested in information, so the informative function of the tax balance in agribusiness is put in the foreground, which enables them to analyze and assess whether the amounts that are due are going to be paid until the deadline.

5. The investors - Bringers of risky capital and their advisers are focused on risks that are characteristic to the investment and return of income of those investments (Škarić Jovanović, 2015), so the allocative function of tax balance sheet in agribusiness is highlighted there as well.

6. Employees - Employees and their representing groups are interested in information on stability and performance of their employers for their security and amount of their earnings, so the informative function of the tax balance sheet in agribusiness is in the foreground.

7. Lenders - Lenders are interested in information which enables them to perform an analysis on whether their loans and corresponding interest will be paid on time and make a decision about it.

8. Customers - Customers are interested in information on the continuation of business operations of the company, especially when they have long-term business relations with it or dependent on that company.

9. Public - Agribusiness companies affect individuals and public in various ways. Companies, for example, can contribute significantly to the local economy in many ways, including hiring more people and procurement of raw materials and consumables from local suppliers, especially when one takes into account the tendency of decentralization of the state apparatus, so the redistribution function of tax balance in agribusiness is in the foreground.

The role of tax balance in agribusiness can be displayed through provision of funds necessary for financing state needs. Since tax balance in agribusiness is seen as a regular and special balance it can be said that if it's a tax balance on company profits or income then it can then be regarded as regular balance. If it is tax balance of establishment, tax balance of legal form change of companies or liquidation tax balance sheet, then it is tax balance as a special balance.

\section{Relation of tax and business balances in agribusiness}

Tax balance in agribusiness is not an independent balance, it respects the principle of jurisdiction of business balances that is, principle of dependence of tax balance in agribusiness compared to business balance. In some cases reverse jurisdiction occurs. If a business balance isn't made, then tax balance is the only and basic financial statement and if the provisions of tax law are more favorable to the agribusiness company from the provisions of trade law.

The principles during evaluation of balance values in tax balance sheet respect the principle of minimum values for evaluating positions of assets and maximum values for evaluating positions of liabilities. 
Principles of dependence of business to tax balance are applied in some European countries, for example Ireland, Netherland, so that the taxable income is determined by correcting business results from the balance sheet (Radovanovic, 1999).

The principle of reverse jurisdiction of business to tax balance in agribusiness is applied in some other countries, for example Italy, Spain. In these countries there is a request to combine business and tax balance, because according to this request balance values determined for tax purposes should be entered in the business balance as well (Radovanovic, 1999).

The central issue for tax balance sheet in agribusiness is the inclusion of latent reserves. ${ }^{4}$ Mainly two methods of inclusion of these reserves are applied. The first is the method of separation in business periods which is applied in Italy, Belgium etc. and according to it tax expenses in agribusinesses are allocated to that accounting period in which it was created. The second method is a static method applied in Netherlands, Ireland etc. According to this method the principle of real separation of business results into business periods is violated in sense that if the changes in tax rates are known on the day of balancing they should be taken into account, regardless if the reserves were created in an earlier accounting period. In the Republic of Serbia until 1991 the principle of reverse jurisdiction was in force, but after the adoption of Corporate Income Tax Law, this principle is no longer valid.

\section{Tax balance in agribusiness in the group of special balances}

In order to determine the correct position for tax balance in agribusiness among other balances and primarily among special balances, one must start from certain limitations that arise during this process.

In the first place restrictions related to normative regulations that regulate this field occur. When we said that tax balance in agribusiness is a member of a group of special balances we mentioned that it is determined by tax norms. For other special balances the characteristic is that they are regulated by commercial law norms.

The following restriction that occurs in expressing relations of tax balance in agribusiness with other special balances is the regularity of preparation. According to this criterion tax balance can be observed as a regular balance. Regular balances are compiled in a predetermined or long-term repeated time periods. The deadline for preparation of these balances is determined by legal norms or internal regulations of a particular agribusiness company. On the other hand, special balances (Vasiljevic, 1970) appear on a case-by-case basis, i.e. when certain conditions occur and circumstances which demand undertaking certain measures. They are compiled in special circumstances that an agribusiness subject may come to during their course of business.

These limitations lead to a conclusion that the sphere of tax balance in agribusiness in the family of special balances is narrowed from certain aspects of observation. This

4 Latent reserves- hidden - have resulted in underestimation of the value of assets of a business entity. 
relation of tax balance in agribusiness with other balances leads us to the field in which certain parallels can be drawn based on balancing procedures.

Tax balance in agribusiness can be observed from the aspect of time dimension, formal and material characteristics compared to other special balances. These dimensions of tax balance in agribusiness will be perceived in the most appropriate way if we primarily start from the characteristics of these balancing groups which are the basis of special balances.

The family of special balances can be observed based on conditionality of individual balances. Such a division of special balances can be found within the division of: status balances and balances with the character of income statement (Rankovic, 1996). Status balances are special balances that show the state in a particular moment, i.e. the overview on a particular day in the business life of an agribusiness subject. Unlike status balances, balances with the character of income statement observe the state and changes which happened in the business life of an agribusiness subject observed from the interval aspect.

Within such observed groups of special balances we will consider the most important characteristics of individual balances in order to show their importance in comparison with tax balance.

Thus observed special balance can be characterized through groups: establishment balance, legal form change balance, fusion balance, separation balance, liquidity balance, financial recovery balance, bankruptcy balance (Škarić Jovanović, Spasić, 2012) and liquidation balance.

Establishment balance precedes the beginning of operations of each agribusiness subject. In order to characterize the formal side of this special balance we must note that the establishment balance is nothing more than a balance sheet. It represents an overview of values of an agribusiness subject's property parts through its foundation. This special balance is enclosed during the establishment of an agribusiness subject. The formal reason for drafting this special balance is the obligation of bookkeeping, and the establishment balance is the necessary condition for opening business records of the subject's business. ${ }^{5}$

The material reason for drafting this kind of special balance is that there is a legal and business need for identifying the financial structure of an agribusiness subject during its foundation, as well as the need of satisfying certain legal minimums in investment

5 The main purpose of business books is for expressing the state and changes in assets, capital and liabilities, to track income and expenses and other business changes. Transferring data from accounting documents into business books is the process of booking. For business books it is characteristic that they are concluded at the end of the financial year (31.12.), and that they are opened at the beginning of the next financial year (01.01.), based on the initial balance. Business books should be managed so that the control of accuracy of booking, storing and usage of data as well as insight into the chronology of time of booking should be available at any time. 
of capital for respective business forms of founding an economic subject.

The basis for preparation of this kind of special balance is an inventory list $^{6}$ of an agribusiness subject that provides another entry of this balance which puts it in the inventories special balances.

Establishment balance depends on the procedures of establishment of an agribusiness subject, and on based on that it must follow the criteria for evaluation of the formation of an agribusiness subject. Accordingly these criteria, we divided (Radovanovic, 178):

1. by the type of investment:

- $\quad$ investment in money;

- investment in natural forms;

- mixed investment;

2. according to the scope of actions taken by the founders:

- single or simultaneous;

- gradual or successive establishment;

3. according to legal starting point:

- new establishment;

- legal form change.

These criteria for establishment of an agribusiness subject affect the establishment balance which forms the basis for its material side.

The following within special balances is legal form change balance of agribusiness subject. It is made in cases when an agribusiness subject changes its legal status and form. Legal form change balance should show the financial status of an agribusiness subject on the day of its legal form change and create a realistic basis for a transparent assessment of its position by the users of balance sheet information (Ignjatijević, et. al., 2015). Precise identification of the date of legal form change of an agribusiness subject is of great importance, because it directly affects the composition of tax balance in agribusiness. It can happen that legal form change of an agribusiness subject occurs at the beginning or end of a business year, in which case the final balance sheet receives the status of legal form change balance sheet. During preparation of a legal form change balance sheet of an agribusiness subject, value stated in the balance deviates from the market value at least for the amount of goodwill. ${ }^{7}$

6 Inventory list is a detailed list of assets of a company on a particular day. In the inventory list assets are expressed individually by type, quantity, price and value. In the global procedure for newly established companies inventory is the first accounting document generated. Its task is to show the property that the newly created company possesses. Balance of establishment is the only balance which is directly derived from the inventory in normal circumstances.

7 Goodwill is the amount paid in excess of the stated bookkeeping value of capital of the purchased legal entity.

EP 2015 (62) 3 (767-780) 
Fusion balance sheet is the following within special balances which is drawn up in cases when integration or merger of two or more agribusiness subjects occurs (Vasiljevic, 1970).

Within fusion balance we differentiate: fusion as assimilation or absorption and fusion as joining or merger. Fusion as absorption represents a process of shutting down one agribusiness subject and a takeover of its assets by the respective agribusiness subject. In this case the economic-legal independence of the absorbed subjects is lost.

Fusion as merger is the process of shutting down two or more agribusiness subjects and the creation of an entirely new agribusiness subject that is entered in a register. In this case, all agribusiness subjects lose their economic-legal independence. During the fusion process the assets of the fused agribusiness subjects is transferred to the newly created agribusiness subject. Agribusiness subjects become tax heirs of the fused agribusiness subjects. In this way the country prevents non-taxation of latent reserves of the fused agribusiness subjects. By expressing the reserves in fusion balance sheet these reserves become the basis for taxation.

Fusion balance sheet is made on the date on which the fusion process of agribusiness subjects was executed. The operating results of the fused agribusiness subjects, from the day of preparation of new fusion balance sheet to the date of completion of the fusion process, are assigned to the newly created agribusiness subject.

During the creation of fusion balance the biggest problem is the question of the amount of equity ownership in the merged agribusiness subject from the fused of agribusiness subjects. This problem is solved by determining the real values of the fused agribusiness subjects, as follows: based on property values, based on the present value of expected cash flows (yield value), based on market value, based on yield value and book value.

In certain cases fusion balance allows the application of a relevant method for determining the amount of equity ownership.

Separation balance sheet is a special balance that shows the value of assets of an agribusiness subject which is the object of separation. In this balance the bookkeeping value of assets and liabilities is adjusted to the actual situation.

This special balance reflects the state that is contrary to the fusion balance sheet, and the most frequent reasons for separation are: with separation of an agribusiness subject its size is reduced with the goal to ensure a more efficient management, separation occurs when a member withdraws from the association etc.

During separation of an agribusiness subject, two types of separation balances appear:

1. balance sheet of a complete agribusiness subject before separation;

2. balance sheet of separated agribusiness subjects.

Balance sheet of a complete agribusiness subject is made on the date of separation, and represents an overview of the entire property and its sources of financing. This balance represents the closing balance of the previous agribusiness subject. As with the fusion balance, the biggest problem here is evaluating property parts. The relevant property parts 
aren't valued by their liquidation values because the agribusiness subject is not liquidated in the classical form. Purchase value isn't adequate either, because with its application latent reserves or hidden losses ${ }^{8}$ can be created, which leads to unequal positions of owners of capital who remain in the old agribusiness subject from the owners who are separated from it. In the event that the separation balance is drawn up at the end of a business year of an agribusiness subject, it is identical to the regular closing balance.

Balance sheets of selected agribusiness subjects are drafted after completed separation, and they are in fact the founding balances of newly established agribusiness subjects. The relations between these two types of separation balances are regulated by respecting the principle of identity. ${ }^{9}$ The relation between these two balances is analogous to the relation between the whole and the parts of a set. By respecting this principle legal security of division of agribusiness subjects is secured and control of separation is ensured. By respecting this principle in this balance, elimination of tax evasion of separated agribusiness entities is ensured. This is in direct accordance with tax balance.

Liquidity balance can be viewed in two ways. According to first this balance is constituted by a lender or a creditor of a particular business entity. The difference that is determined between the value of assets and obligations of a business entity represents the basis of security for loans. This balance is different from regular balances in that way that prices based on which the value of a property is determined are essentially liquidation prices. ${ }^{10}$ According to the second concept, liquidity balance is made for the purpose of determining the state of liquidity of a business entity (Radović, Vitomir, Radaković, 2013) on a specific day of balancing. Assets and liabilities of the balance sheet are grouped in a certain way. ${ }^{11}$ Such grouping allows determining liquidity of a business entity based on this balance. According to this way of grouping, positions of assets are systematized on the principle of increasing liquidity ${ }^{12}$, and the positions of liabilities on the principle of diminishing maturity ${ }^{13}$, or in contrast if the positions of assets are grouped according to the principle of diminishing liquidity, positions of liabilities are grouped according to the principle of increasing maturity.

8 Hidden Losses - latent - have resulted in overestimation of the value of assets of a business entity

9 The principle of identity - represents a requirement that the sum of balances of opening of selected agribusiness subjects, i.e. the sum of their initial balances is equal to the balance of a whole of the separate business entity.

10 Liquidation prices - prices of property parts of a business entity in the event of its liquidation or termination of work.

11 The way of harmonized grouping positions within a balance arises from the request for reviewing the correspondence degree of liquidity of respective assets and due dates for payment of certain obligations of an agribusiness subject.

12 Increasing liquidity of the assets of a balance sheet is achieved by stacking positions that range from fixed assets over inventories and claims all the way to funds.

13 Declining maturity in liabilities of a balance sheet is achieved by stacking positions of own capital through long-term obligations and short-term obligations and all the way to current obligations.

EP 2015 (62) 3 (767-780) 
Financial recovery balance is kind of a special balance, as it is drawn up in a situation where an agribusiness subject is in a financially bad shape. This poor financial situation is the product of momentary lack of funds, which does not necessarily mean that this state will be reflected in long term. Financial recovery balance is the basis for a recovery program (Ranković, 2009), which is adopted for the relevant agribusiness subject. Financial recovery balance, drawn up in accordance with ethical rules of balancing is a statement on the financial position of an agribusiness subject. It gives insight into the structure and scope of financial resources based on which decisions about repair are made.

This balance provides the basis for: write-off of assets and liabilities, which leads to the reduction of both assets and liabilities, additional debt to creditors, which results in an increase in both assets and liabilities, use of reserves to cover losses in order to maintain liquidity of a business entity, reduction of basic capital, conversion of debts of agribusiness subjects in permanent stake of creditors, sale of surplus funds, withdrawal of long-term investments etc.

As the recovery process binds to a specific period of time, so we highlight two types of financial recovery balances: balance before the process of recovery and balance after the recovery process of an agribusiness subject.

Balance before recovery of an agribusiness subject shows the level of indebtedness and the performance of an agribusiness subject and the amount of funds necessary to continue operations, i.e. maintenance of liquidity. The problem when compiling this balance is the expression of hidden losses that are required to be shown in order to create a transparent basis for the rehabilitation process.

Balance after the recovery process depicts the effects of taken measures of restoration on the relevant business entity. This balance should demonstrate that financial position of the business entity which guarantees maintaining liquidity.

Liquidation balance is a special balance sheet that is inevitable at the end of the business entity's operations and its occurrence is more and more common in economic practice. It presents an overview of assets and liabilities of a business entity in the event of liquidation. ${ }^{14}$ The liquidation process represents (Hajnrih, 2012) liquidation of assets of the entity in order to form liquid assets to settle debts.

As liquidation is a process which lasts from the moment that it's decided on liquidation of a business entity to its full liquidation, two types of liquidation balances appear: opening of liquidation balance or initial liquidation balance sheet and completion of liquidation balance or final liquidation balance sheet.

In the process of liquidation, a business entity converts all of its property into liquid assets (money) in order to meet maturing obligations, so the possibility of drafting an in between liquidation balance in the process of liquidation occurs.

14 Liquidation of an agribusiness subjects appears in the event that a business entity doesn't have economic and legal conditions for the continued performance of activity for which it is registered. 
The initial liquidation balance sheet is drawn up before the start of the liquidation process and represents the accounting basis for deciding on liquidation of a business entity. This balance provides data on the real amount of assets, i.e. fixed assets, supplies, claims and cash assets of a business entity on one side and liabilities and own equity on the other. Liquidation balance sheet has to show us the operating results of a business entity for the last accounting period. In this balance assets are valued at liquidation prices, which are lower than purchase prices and especially market prices. The difference between the value of assets valued at liquidation prices and the bookkeeping value of property is entered in the income statement of an agribusiness subject in the liquidation process.

Final liquidation balance is the plan of settlement of liabilities of a business entity in the process of liquidation from the formed liquidation mass ${ }^{15}$. This balance is made after the sale of real property of a business entity and billing of claims. ${ }^{16}$ This balance's assets are comprised of cash and unpaid claims, and liabilities of own equity and obligations.

Bankruptcy balance is a type of special balance that is made with respect to bankruptcy proceedings. It recognizes two types of bankruptcy balances: first is the balance of opening bankruptcy, while the second is closing bankruptcy balance. Initial bankruptcy balance is drawn up by a bankruptcy trustee based on inventory which is also drawn up by him, and not the agribusiness subject in bankruptcy, as is the case with the liquidation balance. The agribusiness subject who is in bankruptcy (Malinić, 2013) doesn't dispose with the property from the moment of entering into the bankruptcy process. In this case, the bankruptcy balance is differentiated from the liquidation balance in relation to the balance user.

\section{Types of tax balances in agribusinesses}

The scientific contribution of this work is in the systematization of forms of tax balances in agribusinesses. The essence of an approach to a problem is in his identification, which in this case represents an overview of tax balances in agribusinesses in one place, their material and formal side. Tax balance in agribusiness viewed from several aspects contributes to its better identification, of which it is necessary to single out that tax balance in relation to the type of agribusiness entity that makes it, can be: tax balance of agribusiness subjects, tax balance of companies and tax balance of corporations i.e. consolidated (Milojevic, Vukoje, Mihajlovic, 2013) tax balance in agribusiness. When we look at tax balance in terms of residence of the agribusiness subject it can be: tax balance of residents and non-residents of the state in whose territory profit is made. When we look in relation to the situation in which tax balance in agribusiness is created it can be: special and regular balance. And finally, if we look at tax balance in agribusiness in terms of business goals of an agribusiness entity it can be: tax balance of profitable and non-profit organizations, and within non-profit organizations two subgroups can be distinguished: tax balance of a non-profit organization that uses the budgetary chart of accounts and non-profit organizations that use chart of accounts for businesses, agribusiness subjects,

15 Assets generated by selling real property of an agribusiness subject out of which due obligations should be paid.

16 Unpaid claims are declared permanently uncollectible and written off in full.

EP 2015 (62) 3 (767-780) 
cooperatives and other organizations. It is important to respect the principle of balancing when drafting a tax balance, where it is particularly important to take into account relevant risks that may occur during tax balancing.

Figure 1. Division of tax balances

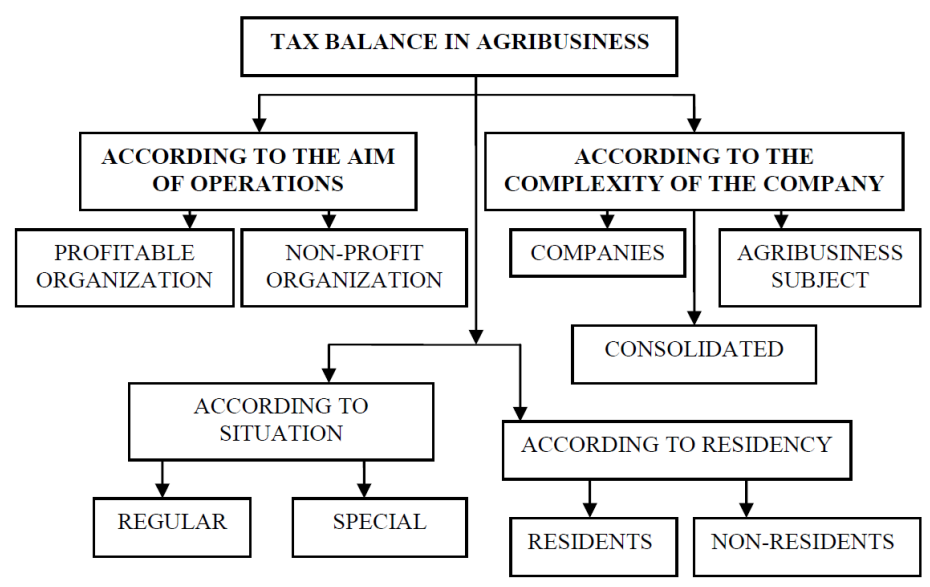

Source: Work of authors

Identification of the tax balance in agribusiness in the system of business organization comes from the purpose and function that satisfies.

\section{Conclusion}

The need for differentiating and precisely determining tax balance in agribusiness refers to adherence to certain principles that are important for that category of balancing. By studying the position of tax balance in agribusiness within many regular and special balances we can conclude that balance as an economic category and its size gives importance to the elements that apply to it by classifying them in a certain order.

When the primary importance is given to the formal and material base of tax balance in agribusiness as a special balance, looking at it through a time dimension we can see that tax balance in agribusiness in its essence belongs to the group of ordinary balances because it is compiled regularly each year, but viewed from the other side, we can find a normative side of tax balance in agribusiness that puts it in special balances. The essence of preparation represents the basis for balancing events that occur in an agribusiness subject. For example, in fusion balance sheet the essence is combining agribusiness subjects and the need to express a new situation, with the liquidation balance sheet the essence is the termination of an agribusiness subject and the need to show the liquidation mass that it owns etc. The same is with tax balance in agribusiness whose preparation depends on the situation which is characteristic to an agribusiness subject. It is known that tax balance in agribusiness is used for determining corporate income tax, and whether the company has to operate the entire year, respectively whether the operating period of a business has to match with the calendar or fiscal year, the answer is that it doesn't. From this we see 
that when liquidation of a company occurs, in addition to liquidation balance sheet, tax balance in agribusiness has to be drawn up as well, due to the necessity of taxing profits. Fusion and separation delay the writing of a tax balance, because the essence of taxing profits no longer refers to one but several persons and vice versa.

From the abovementioned, we can conclude that the importance of tax balance in agribusiness is inasmuch greater because it is linked to all of the moments that occur in the life cycle of an enterprise so the connection with other balances is extremely high. Even though little attention is paid to this balance, its importance is greater because of it, because the unknowns in the field of taxing profits of a company remained incomplete. By defining and theoretically determining tax balance in agribusiness represents the basis in studying this part of accounting balance for easier use, in both theoretical and practical part. Theoretical contribution is to its positioning for easier studying of its characteristics, and practical is the possibility of selecting principles and legal norms in making this kind of balance.

\section{Literature}

1. Hajnrih J. (2012): Specifičnostifinansijskog izveštavanja u postupku likvidacije. Anali Ekonomskog fakulteta u Subotici, no. 27 pp. 66-81.

2. Ignjatijević, S., Milojević, I., Cvijanović, G., Jandrić, M. (2015): Balance of Comparative Advantages in the Processed Food Sector of the Danube Countries, SUSTAINABILITY, vol. 7, no. 6, pp. 6976-6993.

3. Malinić D. (2013): Insuficijencija poslovnih performansi srpske privrede manifestacije, uzroci i glavne smernice oporavka. Ekonomika preduzeća, vol. 61, no. 1-2, pp. 41-62.

4. Milojević, I. (2010) Računovodstvo, Centar za ekonomska i finansijska istraživanja, Beograd.

5. Milojević, I., Pejić, D. (2010): Knjigovodstvo i njegov razvojni put, Oditor, no. 1, pp. 10-16.

6. Milojević, I., Vukoje, A., Mihajlović, M. (2013): Accounting consolidation of the balance by the acquisition method, Ekonomika poljoprivrede, vol. 60, no. 2, pp. 237-252.

7. Radović, M., Vitomir, J., Radaković, M. (2013): ALM koncept u funkciji agregata i resursa banke, Anali Ekonomskog fakulteta u Subotici, no. 29 pp. 255-272.

8. Radovanović, R. (1999): Bilansi preduzeća i banaka, Savremena administracija, Beograd.

9. Ranković, J. (1996): Specijalni bilansi, Ekonomski fakultet, Beograd.

10. Ranković J. (2009): Šta su prioriteti u rešavanju naše ekonomsko-finansijske krize. Ekonomika preduzeća, vol. 57, no. 1-2, pp. 16-21.

11. Ranković, J, (2013): Teorija bilansa, Ekonomski fakultet, Beograd.

12. Savić, B., Vasiljević, Z., Đorđević, D. (2014): Strategijsko upravljanje troškovima kao instrument unapređenja konkurentnosti agrobiznis kompleksa, Ekonomika poljoprivrede, vol. 61, no. 4, pp. 1005-1020.

13. Škarić Jovanović, K. (2015): Primena opreznosti u finansijskom izveštavanju - 
navika ili potreba?, Acta economica, no. 22, pp. 63-82.

14. Škarić Jovanović, K., Spasić, D. (2012): Specijalni bilansi, Ekonomski fakultet, Beograd, Srbija.

15. Vasiljević, K. (1970): Teorija i analiza bilansa, Savremena administracija, Beograd, Srbija.

16. Žager, K., Žager, L. (1999): Analiza financijskih izvještaja, Masmedia, Zagreb, Hrvatska.

\title{
PORESKI BILANS KAO VRSTA SPECIJALNOG BILANSA
}

\author{
Ivan Milojevic ${ }^{17}$, Milorad Zekićc ${ }^{18}$, Zvonko Gobeljićc ${ }^{19}$
}

\section{Rezime}

Tendencija konstantnog usložavanja poslovnih procesa neminovno dovodi do primene sve složenijih instrumenata za potrebe finansijskog izveštavanja u agrobiznisu. U tom sistemu dovodi se u pitanje egzistencijalno mesto i uloga pojedinih elemenata koji menjaju postojeće i dobijaju nove funkcije.

Bilansiranje podrazumeva uređen i konzistentan sistem u kome svaka promena dovodi do nastanka novih relacija menjajući već uspostavljene odnose. Stim u vezi u ovom radu ćemo se fokusirati na mesto i ulogu poreskog bilansa u skupini specijalnih bilansa u agrobiznisu kao veoma značajnoj grupi računovodstvenih instrumenata. Prikazujući korisnike informacija $i$ situacije u kojima se koriste bilansi dobijaju svoje mesto u ovoj klasifikaciji.

Za potrebe primene finanisjskih instrumenata misleći prvenstveno na bilanse u agrobiznisu, neophodno je poznavanje načina njihovog klasifikovanja u zavisnosti od njihove funkcije. Sa ovog aspekta poreski bilans u agrobiznisu je specifičan izveštaj kako po svojoj formalonoj tako i po materijalnoj strukturi, što mu daje osnov za pripadanje kako redovnim tako $i$ specijalnim vrstama bilansa u agrobiznisu.

Ključne reči: porezi, bilansiranje, finanisjski izveštaji, agrobiznis, preduzeće.

17 Redovni profesor, dr Ivan Milojević, Univerzitet za Poslovne Studije Banja Luka, Jovana Dučića br. 23a, Republika Srpska, BiH, Telefon: +381 600702697 E-mail: drimilojevic@gmail.com

18 dr Milorad Zekić, Univerzitet za Poslovne Studije Banja Luka, Jovana Dučića 23a, Republika Srpska, BiH, Telefon: +387 65365 365, E-mail: $\underline{\text { m.zekic22@gmail.com }}$

19 Vanredni profesor, dr Zvonko Gobeljić, Univerzitet Džon Nezbit, Fakultet za kulturu i medije, Goce Delčeva 8, Beograd, Republika Srbija, Telefon: +381112203011, E-mail: zvonko.gobeljic@gmail.com 